\title{
ST. LOUIS ENCEPHALITIS VIRUS: FIRST ISOLATION FROM A HUMAN IN SÃO PAULO STATE, BRAZIL
}

\author{
Iray M. ROCCO(1), Cecília L.S. SANTOS(1), Ivani BISORDI(1), Selma M.C.N. PETRELLA(1), Luiz E. PEREIRA(1), Renato P. SOUZA(1), \\ Terezinha L.M. COIMBRA(1), Thirsa A.F. BESSA(2), Fabiola M. OSHIRO(1), Luciana B.Q. LIMA(1), Matheus P. CERRONI(1), Antonia T. MARTI(1), \\ Vera M. BARBOSA(1), Gizelda KATZ(3) \& Akemi SUZUKI(1)
}

\begin{abstract}
SUMMARY
This paper reports the isolation of St. Louis encephalitis virus (SLEV) from a febrile human case suspected to be dengue, in São Pedro, São Paulo State. A MAC-ELISA done on the patient's acute and convalescent sera was inconclusive and hemagglutination inhibition test detected IgG antibody for flaviviruses. An indirect immunofluorescent assay done on the C6/36 cell culture inoculated with the acute serum was positive for flaviviruses but negative when tested with dengue monoclonal antibodies. RNA extracted from the infected cell culture supernatant was amplified by RT-PCR in the presence of NS5 universal flavivirus primers and directly sequenced. Results of BLAST search indicated that this sequence shares $93 \%$ nucleotide similarity with the sequence of SLEV (strain-MSI.7), confirmed by RT-PCR performed with SLEV specific primers. Since SLEV was identified as the cause of human disease, it is necessary to improve surveillance in order to achieve early detection of this agent in the state of São Paulo and in Brazil. This finding is also an alert to health professionals about the need for more complete clinical and epidemiological investigations of febrile illnesses as in the reported case. SLEV infections can be unrecognized or confused with other ones caused by an arbovirus, such as dengue.
\end{abstract}

KEYWORDS: Saint Louis encephalitis; Flavivirus; Virus isolation; RT/PCR; Genomic sequencing.

\section{INTRODUCTION}

Saint Louis encephalitis virus (SLEV) is an arthropod-borne virus and a member of the Japanese encephalitis virus complex within the genus Flavivirus, family Flaviviridae ${ }^{3}$. SLEV prototype strain (Parton) was isolated in 1933, in Saint Louis, Missouri, USA, from suspensions of brain specimens from deceased patients, by intracerebral inoculation of rhesus monkeys and white mice ${ }^{20}$. In 1941/42, HAMMON et al. established the involvement of wild birds as reservoir hosts and Culex mosquitoes as vectors of the virus ${ }^{20}$.

SLEV is widespread in the Americas and it has been detected from Canada to Argentina. Clinical manifestations range from non-apparent infection to severe cases of encephalitis ${ }^{24}$. Severity of illness increases with advancing age and approximately $90 \%$ of the cases in the elderly lead to encephalitis. Case-fatality rates during epidemics have ranged from 5 to $20 \%$, increasing with age ${ }^{24}$.

The virus was first isolated in northern Brazil in 1969 from a pool of Sabethes belisarioi mosquitoes collected along the Belém-Brasília highway ${ }^{4}$. Despite the wide distribution of SLEV in the Amazon region, verified by serological evidence in birds and humans, to date no epidemic of encephalitis due to the virus has been detected in the region, unlike in the USA where the virus has caused numerous encephalitis outbreaks ${ }^{17}$.

In Brazil only two isolates of SLEV were obtained from human blood, both in the Amazon region, in 1971 and 1978. In both instances, the clinical picture was characterized by a febrile illness with jaundice; no signs of CNS involvement were observed ${ }^{16,24}$.

In the State of São Paulo, between 1967 and 1969, eight SLEV isolations were obtained from rodents, birds and sentinel mice ${ }^{6}$. Neutralizing antibodies $(\mathrm{N})$ were detected by DE SOUZA LOPES et $a l .{ }^{6}$ in humans from areas where the virus was isolated, and by IVERSSON et al. ${ }^{9,10}$ in the Ribeira Valley region in 1977, 1978 and 1980. FERREIRA et al. ${ }^{7}$ found monotypic hemagglutination inhibition (HI) antibodies to SLEV in 49 species of wild birds from the Atlantic forest belonging to 19 families, many of them with migratory habits. Serological inquiries conducted by ROMANO-LIEBER \& IVERSSON $^{21}$ in the Ribeira Valley in 1990 showed, the prevalence of SLEV neutralizing antibodies in residents of ecological reserve JuréiaItatins. No other isolations were obtained until 1993 when the virus was recovered from Anopheles triannulatus and Culex (culex) spp. mosquitoes, collected in the Northwest region of São Paulo (Akemi Suzuki, Adolfo Lutz Institute, unpublished data). In 1996 a 


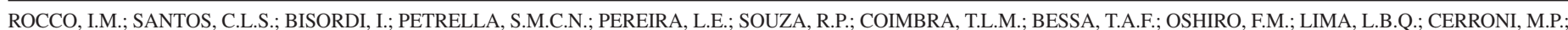
MARTI, A.T.; BARBOSA, V.M.; KATZ, G. \& SUZUKI, A. - St. Louis encephalitis virus: first isolation from a human in São Paulo State, Brazil. Rev. Inst. Med. trop. S. Paulo, 47(5): $281-285,2005$.

seroconversion to SLEV was observed by hemagglutination-inhibition (HI) and neutralization (N) tests in a patient suspected of having an arbovirus illness in the Ribeira Valley5.

This work reports the first isolation of SLEV in the State of São Paulo from the blood of a human case and the results of the laboratory investigations in relation to the case. Dengue (DENV) was suspected initially based on the symptoms, but there was no epidemiological or laboratory evidence to support this diagnosis. Thus, other laboratory investigations were carried out to identify the etiological agent.

\section{MATERIAL AND METHODS}

Patient: On January 21, 2004, a 53-year-old female, physician, was admitted to "Nove de Julho Hospital" in the city of São Paulo for a febrile illness. Symptoms beginning on Jan. 18 included: fever, severe headaches, myalgia, retro orbital pains, somnolence, nausea, vomiting, and a macular rash on the face, neck and thorax, that lasted for one day, and pruritis, mainly on palms and soles. The initial clinical diagnosis was "probable dengue fever".

The patient resided in São Paulo, SP, in an area without Aedes aegypti, but she owns a country house in São Pedro, $180 \mathrm{~km}$ Northeast of São Paulo. Despite the presence of Aedes aegypti in the latter region, no DENV autochthonous transmission had been detected there. She had spent the weekend there nine days before her symptoms began.

An acute blood sample was drawn for tests: hemogram, AST, ALT and GGT. The only alterations observed were the levels of AST (85U/ L), ALT (86U/L) and GGT (137U/L). Specific serological assays were negative for rubella, toxoplasmosis and cytomegalovirus. The patient had fever for seven days and except for severe headaches, no signs of CNS disease were observed. She recovered completely and was discharged after four days of hospitalization.

Laboratory investigation: Acute and convalescent phase serum samples (SPH 253175), taken three and 25 days after onset of illness respectively, were sent to the laboratory of the Center of Zoonosis Control, where the MAC-ELISA for dengue IgM was performed. Because the result was considered inconclusive, the samples were sent to Adolfo Lutz Institute for further serological tests. MAC-ELISA for flavivirus IgM antibodies was performed using the four dengue antigens following the procedure described by KUNO et al. ${ }^{12}$. Serologic assay for IgG antibodies was done by hemagglutination inhibition (HI) with acetone-extracted serum samples ${ }^{22}$, using Dengue serotypes 1, 2 and 3, Ilheus (ILHV), Rocio (ROCV), Yellow fever (YFV) and SLEV flavivirus antigens. Eastern equine encephalitis virus alphavirus antigen was used as negative control.

The first serum sample was inoculated into monolayer cultures of C6/36 Aedes albopictus cells (20 $\mu \mathrm{L} /$ tube) in an attempt to isolate DENV. The cell culture was incubated for nine days at $28{ }^{\circ} \mathrm{C}$. Indirect immunofluorescent antibody (IFA) tests were performed using flavivirus polyclonal antibodies, as well as dengue monoclonal antibodies provided by the U.S. Centers for Disease Control and Prevention, for identification ${ }^{8}$. The first serum sample and the infected C6/36 cell culture supernatant were also inoculated intracerebrally (i.c.) into litters of six newborn Swiss albino mice for virus isolation. The mice were observed daily for signs of illness. Suspensions of infected mouse brain were tested by neutralization (N) assay in mice ${ }^{1}$ using serial dilutions of the brain suspensions (virus) with undiluted hyperimmune ascitic fluid of SPH 253175, Dengue 1 (DENV-1), Iguape (IGUV), ILHV, ROCV, YFV and SLEV. A serum sample from the convalescent phase was tested against its own virus by $\mathrm{N}$.

Molecular studies: Viral RNA was isolated from virus-infected C6/36 culture supernatant using the QIAmpViral RNA Extraction Kit (QIAGEN, Valencia, CA, USA), according to manufacturer's instructions.

Reverse-transcription and amplification reactions (RT-PCR) employed the flavivirus universal primers MA/cFD2 ${ }^{13}$; FU2/cFD2, FU3/ $\mathrm{cFD}^{14}{ }^{14}$. Specific primers for SLEV and West Nile virus (WNV) were also used (Table 1). RT-PCR was conducted in a single reaction tube using the SuperScript ${ }^{\mathrm{TM}}$ One-Step RT-PCR System with Platinium ${ }^{\mathrm{R}}$ Taq DNA Polymerase (Invitrogen, Carlsbad, CA, USA) in the presence of $4 \mu \mathrm{L}$ of viral RNA and $10 \mathrm{pMol}$ of each primer pair in a total reaction volume of $25 \mu \mathrm{L}$. Reverse transcription was performed at $50{ }^{\circ} \mathrm{C}$ for 30 min. After a 3-min denaturation step at $94{ }^{\circ} \mathrm{C}$, cycling times and temperatures proceeded as follows: 30 cycles of $94{ }^{\circ} \mathrm{C}$ for $30 \mathrm{sec}, 45^{\circ} \mathrm{C}$ for $30 \mathrm{sec}$ and $72{ }^{\circ} \mathrm{C}$ for one min in reactions containing NS5 gene primers of Flavivirus genus; 40 cycles of $94{ }^{\circ} \mathrm{C}$ for $30 \mathrm{sec}, 60{ }^{\circ} \mathrm{C}$ for one min, $72{ }^{\circ} \mathrm{C}$ for two min, in reactions employing SLEV or WNV primers. A final extension at $72{ }^{\circ} \mathrm{C}$ for seven min was included in both profiles. The amplification products were analyzed by electrophoresis in a $1.5 \%$ agarose gel, and the separated fragments were visualized by ethidium bromide staining.

Table 1

Oligonucleotide primers used in RT-PCR for SLEV and WNV differentiation

\begin{tabular}{lll}
\hline Primer $^{1}$ & $\begin{array}{l}\text { Genome } \\
\text { position }\end{array}$ & Sequence $\left(5^{\prime}-3^{\prime}\right)$ \\
\hline SLEpme75 & $727-750$ & GTAGCCGACGGTCAATCTCTGTGC \\
SLEpme467 & $1119-1096$ & ACTCGGTAGCCTCCATCTTCATCA \\
WN212 & $233-257$ & TTGTGTTGGCTCTCTTGGCGTTCTT \\
WN619 & $640-616$ & CAGCCGACAGCACTGGACATTCATA \\
WN9483 & $9504-9528$ & CACCTACGCCCTAAACACTTTCACC \\
WN9794 & $9816-9791$ & GGAACCTGCTGCCAATCATACCATC \\
\hline
\end{tabular}

${ }^{1}$ Taller de Vigilancia y Diagostico del Virus del Nilo Occidental, Pergamino, Argentina, 2003. ${ }^{2}$ Genome position of SLEV and WNV specific primers are according to the sequences in GeneBank, respectively: SLE MSI.7 (accession number M16614) and WN NY99 (accession number AF196835).

The products generated in the RT-PCR reactions with the flavivirus universal primers MA/cFD2, FU2/cFD2 and FU3/cFD3 were directly sequenced using the "ABI Prism Big Dye Terminator Cycle Sequencing Ready Reaction Kit” (PE Applied Biosystems, Foster City, CA, USA) following manufacturer's protocol. Nucleic acid sequence analysis was performed on an automated Applied Biosystems 377 DNA sequencer.

Sequence data from this study has been deposited with GenBank Data Libraries under Accession Number AY825077.

Eco-epidemiological studies: Wild birds were captured with mist 


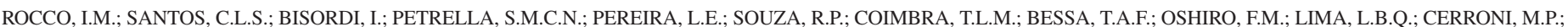

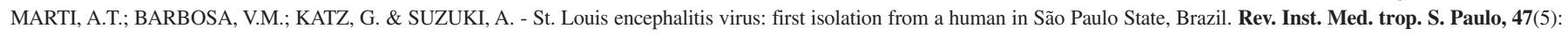
281-285, 2005.

nets set up for three days, from May 18 to 22, 2004 on the boundaries of and inside forests in a wooded area of about $50,000 \mathrm{~m}^{2}$ and also around patient's dwelling in São Pedro. The birds were bled by puncture of the jugular vein, identified, banded and released. The blood samples were collected $(0.3 \mathrm{~mL})$ into a sterile syringe containing $1.2 \mathrm{~mL}$ of $0.75 \%$ phosphate buffered bovine albumin at $\mathrm{pH} 7.4$ and heparin. Plasmas were separated by centrifugation and used for HI test with 2fold dilutions starting at 1 in 20 . In attempt to virus isolation plasmas were also inoculated i.c. into newborn mice. Families of sentinel mice (one mother and six newborns) were exposed for three days in the same places where the birds were captured and then placed under laboratory observation for 21 days.

Mosquitoes were collected at night using CDC light-traps. The mosquitoes were identified, ground in phosphate buffered salina, $\mathrm{pH}$ 7.4 with $1.8 \%$ bovine albumin. After centrifugation at $11.000 \mathrm{x}$ g for 30 minutes the supernatants were inoculated i.c. into newborn mice.

\section{RESULTS}

The convalescent phase serum diluted 1:40 presented optical density (OD) of 0.142 by MAC ELISA. An OD $\geq 0.200$ is considered positive, while values between 0.100 and 0.200 are the limits. Seroconversion for flavivirus group IgG antibodies was demonstrated by HI (Table 2).

No cytopathic effect was observed in C6/36 cells after nine days. An IFA test on some of the cells was positive for flavivirus, but negative for the four DENV serotypes, using monoclonal antibodies.

RNA extracted from the infected C6/36 cell culture supernatant was amplified by RT-PCR in the presence of the flavivirus universal primers, MA/cFD2, FU2/cFD2, FU3/cFD3 ${ }^{13,14}$, designed to cover approximately $1 \mathrm{~kb}$ at the 3' terminus of the NS5 gene of the Flavivirus genus. Specific amplified products were generated in the RT-PCR reactions allowing direct sequencing reactions. A fragment of 1020 nucleotides was obtained, after assembling the sequences of the three overlapping fragments. Results of the BLAST search indicated that this sequence shared $93 \%$ nucleotide similarity with the published sequence of the Mississippi 1975 SLEV strain-MSI.7 (GenBank accession number AF013416). To confirm that RNA isolated from the patient was from SLEV, a RT-PCR assay was performed with primers designed to specifically differentiate between SLEV and WNV infection. As shown in Fig. 1, strong amplification of the expected fragment of $392 \mathrm{bp}$ was obtained with the SLEV primer set. No amplifications of WNV sequences were observed.

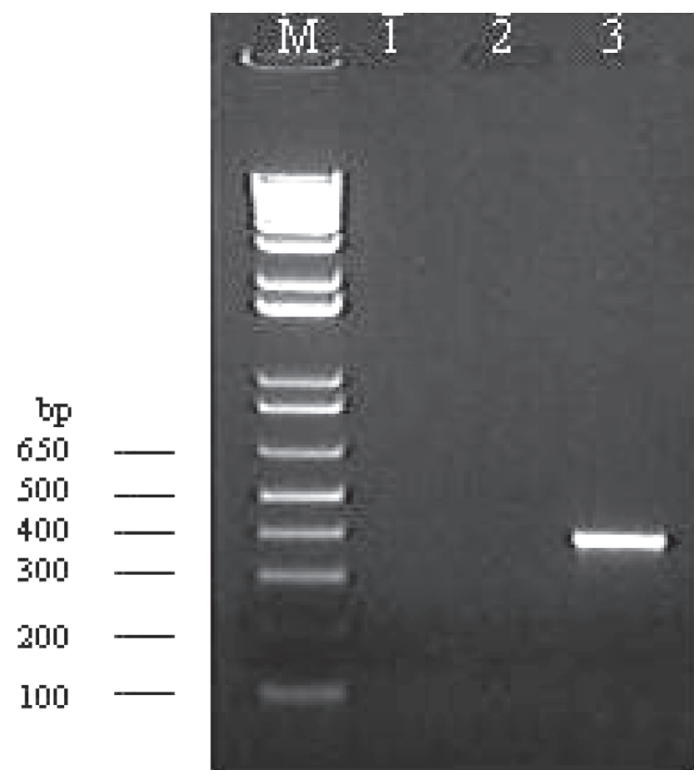

Fig. 1 - Agarose gel electrophoresis analysis of RT-PCR products from RNA extracted from supernatant of C6/36 cells infected with patient's acute phase serum, with the following primers pairs: (1) WN212/WN619c; (2) WN9483/WN9794; (3) SLEPme75/SLEPme467c); (M) $1 \mathrm{~kb}$ plus DNA Ladder (Invitrogen ${ }^{\mathrm{TM}}$, Carlsbad, CA, USA) molecular marker.

The virus was isolated successfully in suckling mice. The onset of symptoms was on day 3 after inoculation, two mice were collected on the $5^{\text {th }}$ day and two more on the $6^{\text {th }}$ day, on day seven the last two died.

Results of mouse $\mathrm{N}$ tests showed that the strongest cross-reaction occurred with the virus isolated and the standard strain of SLEV, with a log of neutralization index (LNI) of 3.9. A low level of cross-reactivity occurred with DENV, IGUV, ILHV, ROCV and YFV, with a LNI from 0.9 to 1.8 . The patient convalescent serum presented a LNI of 1.9 to the isolated virus (Table 3).

A total of 47 plasma samples from wild birds belonging to families Emberezinae (14), Columbidae (8), Turdidae (6), Formicariidae (5), Tyrannidae (5), Trochilidae (4), Furnariidae (3), Pipridae (1) and Troglodytidae (1) were tested. All plasma samples were negative by HI assay. Four hundred and eighty-two mosquitoes belonging to Culex ( $\mathrm{Cux}$ ) sp. (380), Mansonia (Man) sp. (63), Aedes sp. (20), Ochlerotatus scapularis (14), Coquillettidia sp. (4) and Anopheles (Nys) sp. (1) were captured. No virus was isolated from birds, mosquitoes or the sentinel mice.

Table 2

Results of the HI tests done on the patients with various arbovirus antigens

\begin{tabular}{lccccccc}
\hline Patient sera & \multicolumn{5}{c}{ Antigens } \\
\cline { 2 - 7 } & EEEV & DENV-1 & DENV-2 & DENV-3 & ILHV & ROCV & SLEV \\
\hline Acute & 0 & 0 & 0 & 0 & 0 & 0 & 0 \\
Convalescent & 0 & 80 & 20 & 160 & 1,280 & 80 & 640 \\
\hline
\end{tabular}

EEEV = eastern equine encephalitis virus (SPAn 14723); DENV-1 = dengue virus type 1 (Hawaii); DENV-2 = dengue virus type 2 (TR 1751); DENV-3 = dengue virus type 3 (H 87); ILHV = Ilheus virus (BeH 7445); ROCV = Rocio virus (SPH 34675); SLEV = Saint Louis encephalitis virus (SPAn 11916); YFV = Yellow fever virus (BeH 111). 


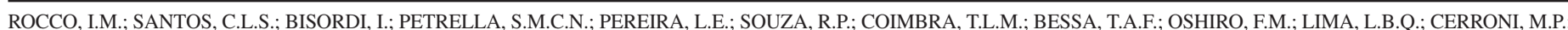
MARTI, A.T.; BARBOSA, V.M.; KATZ, G. \& SUZUKI, A. - St. Louis encephalitis virus: first isolation from a human in São Paulo State, Brazil. Rev. Inst. Med. trop. S. Paulo, 47(5): $281-285,2005$.

Table 3

Results of mouse neutralization tests showing the relationship of the isolated virus (SPH 253175) and other flavivirus

\begin{tabular}{|c|c|c|c|c|c|c|c|}
\hline \multirow[t]{2}{*}{ Immune sera } & \multicolumn{7}{|c|}{ Virus } \\
\hline & SPH 253175 & SLEV & ROCV & ILHV & IGUV & YFV & DENV-1 \\
\hline SPH $253175^{1}$ & 1.9 & - & - & - & - & - & - \\
\hline SPH 253175 & 3.5 & - & - & - & - & - & - \\
\hline SLEV & 3.9 & 3.7 & - & - & - & - & - \\
\hline ROCV & 1.7 & - & 3.6 & - & - & - & - \\
\hline ILHV & 1.8 & - & - & 3.6 & - & - & - \\
\hline IGUV & 1.8 & - & - & - & 4.5 & - & - \\
\hline YFV & 1.8 & - & - & - & - & 4.3 & - \\
\hline DENV-1 & 0.9 & - & - & - & - & - & 3.6 \\
\hline
\end{tabular}

Values represent log of the neutralization index (LNI): ${ }^{1}$ convalescent phase serum; SLEV = Saint Louis encephalitis virus (SPAn 11916); ROCV = Rocio virus (SPH 34675); ILHV = Ilheus virus (BeH 7445); IGUV = Iguape virus (SPAn 71686); YFV = Yellow fever virus (BeH 111); DENV-1 = dengue virus type 1 (Hawaii); - = not tested.

\section{DISCUSSION}

This is the first isolation of SLEV from a human case in the State of São Paulo, Brazil. It seems likely that the infection was acquired in São Pedro, where the patient stayed nine days prior to onset of illness. This finding is also an alert to health professionals about the need for more complete clinical and epidemiological investigations of febrile illnesses such as in the reported case. Some of the symptoms presented by the patient, such as rash and pruritis on palms and soles are not described in the literature. It is unlikely that this case was the only one; the virus may be circulating silently, or causing clinical symptoms similar to those observed in DENV. Such cases could easily be unrecognized or confused with other arbovirus infections. In the State of São Paulo there are many regions in which there is DENV transmission, and the symptoms in this case were much more similar to those described for DENV than the clinical picture described in the literature for SLEV infection.

SLEV antibodies have been detected in the State more frequently in the Ribeira Valley region 5,6,7,9,10,21, where in the 70's ROCV virus was isolated and caused a severe encephalitis epidemic. However, no clinical cases of SLEV infection were observed. SLEV isolation from mosquitoes in the northwest of the state and the related case demonstrated that the virus has been circulating in other regions of the state.

The clinical picture for SLEV is diverse. Human cases have been documented in the United States since $1933^{20}$, varying from mild sporadic cases to outbreaks of severe encephalitis. An exception of this pattern is the Coachella Valley in southern California where SLEV has been also detected regularly, but clinical disease has not been reported $^{18,19}$. In Brazil clinical cases of SLEV are rarely recognized, in spite of the fact that the virus circulates in birds, mosquitoes and humans ${ }^{5,6,7,9,10,17,21,25}$. One of the possible explanations for these distinct dynamics could be the strain virulence. Phenotypic variations between strains have been described ${ }^{2,11,15,23,24}$.

Specific primers for WNV were employed in RT-PCR because of the antigenic relationship between SLEV and WNV. The introduction of the latter virus into Brazil had to be considered since WNV has caused epidemics in North America and can be transported by means of migration of viremic birds.

The field sampling was insufficient to allow a definitive conclusion about the presence of SLEV in the area and further studies are required to elucidate the natural transmission cycle of the virus in the region. The present case is very important since SLEV was identified as the cause of human disease and points out the necessity to improve surveillance in order to achieve early detection of this agent in the state of São Paulo and in Brazil.

\section{RESUMO}

\section{Vírus da encefalite São Luis: primeiro isolamento de humano no Estado de São Paulo, Brasil}

O presente estudo relata o isolamento do vírus da encefalite São Luis (SLEV) de um caso febril humano suspeito de dengue, em São Pedro, Estado de São Paulo. MAC-ELISA realizado com soros das fases aguda e convalescente foi inconclusivo e anticorpos IgG foram detectados por inibição da hemaglutinação para flavivirus. Imunofluorescência indireta com cultura de células C6/36 inoculadas com soro da fase aguda foi positivo para flavivirus mas negativo quando testado com anticorpos monoclonais para dengue. O RNA extraído de cultura de células infectadas foi amplificado na presença de primers universais para o gênero Flavivirus, deduzidos de uma região da proteína não estrutural 5 e diretamente sequenciado. Os resultados da pesquisa no BLAST indicaram que a seqüência apresenta $93 \%$ de similaridade de nucleotídeos com a sequiência de SLEV (cepa MS1.7), confirmado por RT-PCR, realizado com primers específicos para SLEV. $\mathrm{O}$ fato de SLEV ter sido identificado como a causa de doença humana indica a necessidade de aprimorar a vigilância a fim de detectar precocemente esse agente no Estado de São Paulo e no Brasil. Esse caso é também um alerta para os profissionais de saúde sobre a necessidade de investigações clínicas e epidemiológicas mais completas sobre doenças febris como no caso relatado. Infecções por SLEV podem não ser reconhecidas ou confundidas com outras causadas por arbovírus como a dengue. 


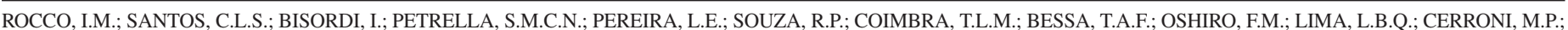

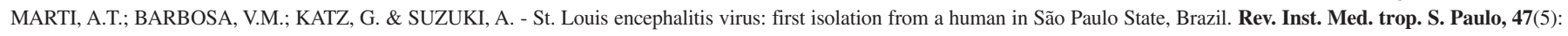
281-285, 2005.

\section{ACKNOWLEDGMENTS}

We are grateful to Esther Luiza Bocatto Chamelet for her valuable technical assistance in viral confirmation. Thanks are also due to the Section of Breeding Animals and Cell Culture of Adolfo Lutz Institute for their technical support and to the staff of the Infectology Unit of Nove de Julho Hospital. CLSS is financially supported by FAPESP and CNPq.

\section{REFERENCES}

1. BEATY, B.J.; CALISHER, C.H. \& SHOPE, R.E. - Arboviruses. In: SCHIMIDT, N.J. \& EMMONS, E., ed. Diagnostic procedures for viral, rickettsial and chlamydial infections. 6. ed. Washington, American Public Health Association, 1989. p. $797-$ 855 .

2. BOWEN, G.S.; MONATH, T.P.; KEMP, G.E.; KERSCHNER, J.H. \& KIRK, L.J. Geographical variation among St. Louis encephalitis virus strains in the viremic response of avian hosts. Amer. J. trop. Med. Hyg., 29: 1411-1419, 1980.

3. CALISHER, C.H.; KARABATSOS, N. \& DALRYMPLE, J.M. - Antigenic relationships among flaviviruses as determined by cross-neutralization tests with polyclonal antisera. J. gen. Virol., 70: 37-43, 1989.

4. CAUSEY, O.R.; SHOPE, R.E. \& THEILER, M. - Isolation of St. Louis encephalitis virus from arthropods in Pará, Brazil. Amer. J. trop. Med. Hyg., 13: 449, 1964.

5. COIMBRA, T.L.M.; NASSAR, E.S.; FERREIRA, I.B. et al. - Serologic evidence of human infection by Saint Louis encephalitis virus in Registro, Ribeira Valley, São Paulo State, Brazil. Virus Rev. Res., 2 (suppl.): 166, 1997.

6. DE SOUZA LOPES, O.; DE ABREU SACCHETTA, L.; COIMBRA, T.L.M. \& PEREIRA, L.E. - Isolation of St. Louis encephalitis virus in South Brazil. Amer. J. trop. Med. Hyg., 28: 583-585, 1979.

7. FERREIRA, I.B.; PEREIRA, L.E.; ROCCO, I.M. et al. - Surveillance of arbovirus infections in the Atlantic Forest region, State of São Paulo, Brazil. I. Detection of hemagglutination-inhibiting antibodies in wild birds between 1978 and 1990. Rev. Inst. Med. trop. S. Paulo, 36: 265-274, 1994.

8. GUBLER, D.J.; KUNO, G.; SATHER, G.E.; VELEZ, M. \& OLIVER, A. - Mosquito cell cultures and specific monoclonal antibodies in surveillance for dengue viruses. Amer. J. trop. Med. Hyg., 33: 158-165, 1984.

9. IVERSSON, L.B.; TRAVASSOS DA ROSA, A.P.A. \& TRAVASSOS DA ROSA, J. Estudos sorológicos para pesquisa de anticorpos de arbovírus em população humana da região do Vale do Ribeira. II. Inquérito em pacientes do Hospital Regional de Pariquera-Açu, 1980. Rev. Saúde públ. (S. Paulo), 15: 587-602, 1981.

10. IVERSSON, L.B.; TRAVASSOS DA ROSA, A.P.A.; TRAVASSOS DA ROSA, J. et al. Estudos sorológicos para pesquisa de anticorpos de arbovírus na população humana da região do Vale do Ribeira. I. Seguimento sorológico de grupo populacional residente em ambiente silvestre. In: SIMPÓSIO INTERNACIONAL SOBRE ARBOVÍRUS DOS TRÓPICOS E FEBRES HEMORRÁGICAS, 1., Belém, 1980. Anais. p. 229-243.

11. KRAMER, L.D.; PRESSER, S.B.; HARDY, J.L. \& JACKSON, A.O. - Genotypic and phenotypic variation of selected Saint Louis encephalitis viral strains isolated in California. Amer. J. trop. Med. Hyg., 57: 222-229, 1997.
12. KUNO, G.; GOMEZ, I. \& GUBLER, D.J. - Detecting artificial anti-dengue IgM immune complexes using an enzyme-linked immunosorbent assay. Amer. J. trop. Med. Hyg., 36: 153-159, 1987.

13. KUNO, G. - Universal diagnostic RT-PCR protocol for arboviruses. J. virol. Meth., 72: 27-41, 1998

14. KUNO, G.; CHANG, G.J.; TSUCHIYA, K.R.; KARABATSOS, N. \& CROPP, C.B. Phylogeny of the genus Flavivirus. J. Virol., 72: 73-83, 1998.

15. MONATH, T.P.; CROPP, C.B.; BOWEN, G.S. et al. - Variations in virulence for mice and rhesus monkeys among St. Louis encephalitis virus strains of different origin. Amer. J. trop. Med. Hyg., 29: 948-962, 1980.

16. PINHEIRO, F.P.; LE DUC, J.W.; TRAVASSOS DA ROSA, A.P.A. \& LEITE, O.F. Isolation from St. Louis encephalitis virus from a patient in Belém, Brazil. Amer. J. trop. Med. Hyg., 30: 145-148, 1981.

17. PINHEIRO, F.P.; TRAVASSOS DA ROSA, A.P.A.; FREITAS, R.B. et al. - Arboviroses Aspectos clínicos epidemiológicos. In:. Instituto Evandro Chagas 1936-1986, 50 anos de contribuição às ciências biológicas e à medicina tropical. Belém, Fundação SESP, 1986. v. 1, p. 375-408.

18. REISEN, W.K.; CHILES, R.E.; LOTHRUP, H.D.; PRESSER, S.B. \& HARDY, J.L. Prevalence of antibodies to mosquito-borne encephalitis viruses in residents of the Coachella Valley, California. Amer. J. trop. Med. Hyg., 55: 667-671, 1996.

19. REISEN, W.K.; LOTHROP, H.D.; CHILES, R.E. et al. - Persistence and amplification of St. Louis encephalitis virus in Coachella Valley of California, 2000-2001. J. med. Entomol., 39: 793-805, 2002.

20. REISEN, W.K. - Epidemiology of St. Louis encephalitis virus. Advanc. Virus Res., 61: 139-183, 2003.

21. ROMANO-LIEBER, N.S. \& IVERSSON, L.B. - Inquérito soroepidemiológico para pesquisa de infecções por arbovírus em moradores de reserva ecológica. Rev. Saúde públ. (S. Paulo), 34: 236-242, 2000.

22. SHOPE, R.E. \& SATHER, G.E. - Arboviruses. In: LENNETTE, E.H. \& SCHIMIDT, N.J., ed. Diagnostic procedures for viral, rickettsial and chlamydial infections. 5. ed. Washington, American Public Health Association, 1979. p. 767-814.

23. TRENT, D.W.; GRANT, J.A.; VORNDAM, A.V. \& MONATH, T.P - Genetic heterogeneity among Saint Louis encephalitis virus isolates of different geographic origin. Virology, 114: $319-332,1981$

24. TSAI, T.F. \& MITCHELL, C.J. - St. Louis encephalitis. In: MONATH, T.P., ed. The arboviruses: epidemiology and ecology. Boca Raton, CRC Press, 1986. v. 4, p. 113-143.

25. VASCONCELOS, P.F.C.; TRAVASSOS DA ROSA, A.P.A.; PINHEIRO, P.F. et al. Arboviruses pathogenic for man in Brazil. In: TRAVASSOS DA ROSA, A.P.A.; VASCONCELOS, P.F.C. \& TRAVASSOS DA ROSA, J.F.S., ed. An overview of arbovirology in Brazil and neighbouring countries. Belém, Instituto Evandro Chagas, 1998. p. 72-99.

Received: 20 May 2005

Accepted: 18 August 2005 